\title{
Influence of Different Fertility Management Practices on Productivity and Economics of Forage Soybean
}

Waseem Raja ${ }^{1}$, M. Anwar Bhat ${ }^{1}$, B.A. Allie ${ }^{2}$, Intikhab A. Jehangir ${ }^{3}$, Ashaq Hussain ${ }^{3}$

10.18805/ag.D-5439

\begin{abstract}
Background: Quality and higher fodder production is one of the important aspects to get higher productivity from live stock. India suffer a net deficiency of $35.6 \%$ green fodder, $10.95 \%$ dry crop residues and Jammu and Kashmir faces a net deficit of $19 \%$ in fodder. The choice to grow cultivated fodder crops during kharif season in Kashmir is limited and are grown generally under rainfed conditions. The major kharif season fodder cereal crops are maize and sorghum and the legume fodder crops are cowpea and soybean. To improve the quality and yield of fodder crops, it is important to standardise production technology for legume fodder crops.

Methods: A field experiment was undertaken at Agronomy Farm, Faculty of Agriculture, Wadura of Sher-e-Kashmir University of Agricultural Sciences and Technology of Kashmir during kharif 2019 and 2020 to study the impact of different fertility management practices on productivity and economics of forage soybean. The experiment comprising of seven treatments laid out in a randomized complete block design with three replications.

Result: Application of $\mathrm{N}, \mathrm{P}_{2} \mathrm{O}_{5}, \mathrm{~K}_{2} \mathrm{O}(30,90,45 \mathrm{~kg} / \mathrm{ha})$ along with 0.1 tons/ha vermicompost recoded higher green fodder productivity and growth characters of soybean. However application of $\mathrm{N}, \mathrm{P}_{2} \mathrm{O}_{5}, \mathrm{~K}_{2} \mathrm{O}(20,60,30 \mathrm{~kg} / \mathrm{ha})$ was found economically viable option.

Key words: Fodder, Quality, Soybean, Soil fertility.
\end{abstract}

\section{INTRODUCTION}

India suffer a net deficiency of $35.6 \%$ green fodder, $10.95 \%$ dry crop residues and $44 \%$ concentrate feed ingredients (IGFRI Vision, 2050). In Jammu and Kashmir, 0.6 lakh ha is under cultivated fodder crops and faces a net deficit of $19 \%$ in fodder (Raja, 2013). The choice to grow cultivated fodder crops during kharif season in Kashmir is limited and are grown generally under rainfed conditions. The major kharif season fodder cereal crops are maize and sorghum and the legume fodder crops are cowpea and soybean. Among the legume fodder crops the soybean produced higher fodder yield as reported by Ummaisa, (2020). Therefore, to increase further the productivity of fodder soybean under rainfed conditions one of the option is to supply the nutrients in optimum level. The vermicompost was proven an important organic manure in supplying nutrients to agricultural crops and has attracted the researchers throughout the globe in past few decades. Proper rate of vermicompost along with chemical fertilizer is imperative to supply the nutrients to soybean fodder crop to get higher quality and production. Keeping these aspects in view the present investigation was undertaken to study influence of different rates of vermicompoast and chemical fertilizers on growth, fodder yield and quality of fodder soybean.

\section{MATERIALS AND METHODS}

Field experiments were conducted during kharif 2019 and 2020 under rainfed condtions at Faculty of Agriculture Wadura, Sher-e-Kashmir University of Agricultural Science and technology Kashmir to find out the rate of vermicompost and $\mathrm{N}, \mathrm{P}_{2} \mathrm{O}_{5}, \mathrm{~K}_{2} \mathrm{O}$ on fodder soybean. The study area falls in temperate climatic zone of Kashmir Valley. The soil of
1Division of Agronomy, Faculty of Agriculture, Wadura, Sher-eKashmir University of Agricultural Sciences and Technology Kashmir, Srinagar-190 001, Jammu and Kashmir, India.

${ }^{2}$ ARSSSS, Pampore, Sher-e-Kashmir University of Agricultural Sciences and Technology Kashmir, Srinagar-190 001, Jammu and Kashmir, India.

${ }^{3}$ Mountain Research Centre for Field Crops Khudwani, Sher-eKashmir University of Agricultural Sciences and Technology Kashmir, Srinagar-190 001, Jammu and Kashmir, India.

Corresponding Author: Waseem Raja, Division of Agronomy, Faculty of Agriculture, Wadura, Sher-e-Kashmir University of Agricultural Sciences and Technology Kashmir, Srinagar-190 001, Jammu and Kashmir, India. Email: waseemra1@gmail.com

How to cite this article: Raja, W., Bhat, M.A., Allie, B.A., Jaheangir, I.A., Hussain, A. (2021). Influence of Different Fertility Management Practices on Productivity and Economics of Forage Soybean. Agricultural Science Digest. DOI: 10.18805/ag.D-5439.

Submitted: 30-06-2021 Accepted: 29-10-2021 Online: 01-01-2021

experimental field was clay loam in texture, high in organic carbon $(2.3 \%)$, medium in available phosphorus $(13.2 \mathrm{~kg}$ $\mathrm{ha}^{-1}$ ), available potassium (327 $\mathrm{kg} \mathrm{ha}^{-1}$ ) and low in available nitrogen (128 kg ha-1). The fertility levels were $\mathrm{N}, \mathrm{P}_{2} \mathrm{O}_{5}, \mathrm{~K}_{2} \mathrm{O}$ $\mathrm{kg} / \mathrm{ha} \mathrm{T}_{1}(0,0,0), \mathrm{T}_{2}(10,30,15), \mathrm{T}_{3}(20,60,30), \mathrm{T}_{4}(30,90$, 45 ) and $T_{5}\left(T_{2}+0.1\right.$ ton/ha V.C $), T_{6}\left(T_{3}+0.1\right.$ ton/ha V.C $), T_{7}$ $\left(\mathrm{T}_{4}+0.1\right.$ tons/ha V.C) were assigned to RBD with three replication. 'Shalimar soybean-1' variety of soybean was sown at $30 \mathrm{~cm}$ row to row spacing during both years of investigation. The experiment was conducted under rainfed conditions. The vermicompost as per the treatments was 
applied in the rows at the time of sowing. The nitrogen through urea, phosphorus through diammonium phosphate and potassium through muriate of potash as per treatments was applied as basal. For dry matter accumulation the samples were taken at the time of harvest and dried in shade, then oven dried at $60^{\circ} \mathrm{C}$ for 72 hours. Samples were weighed to a constant weight and dry matter was expressed as tonnes/ha. For economic analysis (benefit cost ratio) cost of inputs and price of outputs were calculated at prevailing market price.

\section{RESULTS AND DISCUSSION}

\section{Plant height and dry matter accumulation}

The fertility management practices induced significant difference in plant height and dry matter accumulation of

Table 1: Weather parameters during the crop growth period (2019 and 2020).

\begin{tabular}{lcccc}
\hline & $\begin{array}{c}\text { Crop growth } \\
\text { duration (days) }\end{array}$ & \multicolumn{2}{c}{$\begin{array}{c}\text { Mean temperature } \\
\left({ }^{\circ} \mathrm{C}\right)\end{array}$} & $\begin{array}{c}\text { Rainfall } \\
(\mathrm{mm})\end{array}$ \\
\hline Year & & Max & Min & \\
\hline 2019 & 83 & 30.7 & 14.3 & 133.0 \\
2020 & 82 & 30.8 & 14.0 & 126.5 \\
\hline
\end{tabular}

soybean (Table 2). In general the growth characters (plant height and dry matter accumulation) of soybean were higher in 2019 compared to 2020 . This is due to higher rainfall during the crop growth period in year 2019 compared to 2020 (Table 1). Taller plants were recorded with integrated approach (Chemical fertilizer + vermicompost) than to their corresponding chemical fertilizers alone. The data of two years showed that $T_{7}$ recorded significantly taller plants than $\mathrm{T}_{5}, \mathrm{~T}_{4}, \mathrm{~T}_{3}, \mathrm{~T}_{2}$ and $\mathrm{T}_{1}$, however was statistically at par to $\mathrm{T}_{6}$. Further T6 recorded significantly higher plant high than $T_{3}$, $T_{2}$ and $T_{1}$. The mean dry matter accumulation was also observed higher in treatment $T_{7}(9.1 \mathrm{t} / \mathrm{ha})$ followed by $T_{6}$ (8.8 t/ha) $\mathrm{T}_{4}$ (8.3 t/ha), $\mathrm{T}_{5}(8.2 \mathrm{t} / \mathrm{ha}), \mathrm{T}_{3}(8.1), \mathrm{T}_{2}(7.5 \mathrm{t} / \mathrm{ha})$ and lowest in $T_{1}(6.4 \mathrm{t} / \mathrm{ha})$. This is attributed to increased availability of nutrients with application vermicompost with chemical fertilizers. Also the increased rate of vermicompost and chemical fertilizer will have increased the availability of nutrients which have resulted in higher plant height and dry matter accumulation. Similar findings were reported by Chaudhani et al., (2019), Jagdeesh et al., (2018), Verma et al., (2017) and Maeshbabu et al., (2008).

\section{Green fodder yield and economics}

The green fodder yield of soybean was higher during 2019 compared to 2020. Moreover nearly similar trend was

Table 2: Effect of fertility management practices on plant height, dry matter of soybean.

\begin{tabular}{|c|c|c|c|c|}
\hline \multirow[t]{2}{*}{ Treatment } & \multicolumn{2}{|c|}{$\begin{array}{l}\text { Plant height } \\
(\mathrm{cm})\end{array}$} & \multicolumn{2}{|c|}{$\begin{array}{l}\text { Drymatter accumulation } \\
\qquad(\mathrm{t} / \mathrm{ha})\end{array}$} \\
\hline & 2019 & 2020 & 2019 & 2020 \\
\hline $\mathrm{T}_{1}:$ Control & 55.0 & 45.4 & 7.6 & 5.2 \\
\hline $\mathrm{T}_{2}: \mathrm{N}, \mathrm{P}_{2} \mathrm{O}_{5}, \mathrm{~K}_{2} \mathrm{O}(10,30,15 \mathrm{~kg} / \mathrm{ha})$ & 58.0 & 51.6 & 8.7 & 6.3 \\
\hline $\mathrm{T}_{3}: \mathrm{N}, \mathrm{P}_{2} \mathrm{O}_{5}, \mathrm{~K}_{2} \mathrm{O}(20,60,30 \mathrm{~kg} / \mathrm{ha})$ & 63.2 & 54.0 & 9.4 & 6.8 \\
\hline $\mathrm{T}_{4}: \mathrm{N}, \mathrm{P}_{2} \mathrm{O}_{5}, \mathrm{~K}_{2} \mathrm{O}(30,90,45 \mathrm{~kg} / \mathrm{ha})$ & 64.3 & 54.7 & 9.6 & 7.0 \\
\hline $\mathrm{T}_{5}: \mathrm{N}, \mathrm{P}_{2} \mathrm{O}_{5}, \mathrm{~K}_{2} \mathrm{O}(10,30,15 \mathrm{~kg} / \mathrm{ha})+0.1$ tons $/$ ha V.C & 60.1 & 52.7 & 9.7 & 6.7 \\
\hline $\mathrm{T}_{6}: \mathrm{N}, \mathrm{P}_{2} \mathrm{O}_{5}, \mathrm{~K}_{2} \mathrm{O}(20,60,30 \mathrm{~kg} / \mathrm{ha})+0.1$ tons/ha V.C & 67.7 & 59.6 & 10.5 & 7.2 \\
\hline $\mathrm{T}_{7}: \mathrm{N}, \mathrm{P}_{2} \mathrm{O}_{5}, \mathrm{~K}_{2} \mathrm{O}(30,90,45 \mathrm{~kg} / \mathrm{ha})+0.1$ tons/ha V.C & 70.0 & 60.5 & 10.9 & 7.4 \\
\hline $\mathrm{S}, \mathrm{Em} \pm$ & 1.30 & 1.27 & 0.37 & 0.24 \\
\hline C.D & 4.06 & 4.04 & 1.01 & 0.73 \\
\hline
\end{tabular}

Table 3: Effect of fertility management practices on green fodder yield and benefit cost of soybean.

\begin{tabular}{|c|c|c|c|c|}
\hline \multirow[t]{2}{*}{ Treatment } & \multicolumn{2}{|c|}{$\begin{array}{l}\text { Green fodder yield } \\
(\mathrm{t} / \mathrm{ha})\end{array}$} & \multicolumn{2}{|c|}{$\mathrm{B}: \mathrm{C}$} \\
\hline & 2019 & 2020 & 2019 & 2020 \\
\hline $\mathrm{T}_{1}$ : Control & 26.0 & 21.5 & 3.02 & 2.50 \\
\hline $\mathrm{T}_{2}: \mathrm{N}, \mathrm{P}_{2} \mathrm{O}_{5}, \mathrm{~K}_{2} \mathrm{O}(10,30,15 \mathrm{~kg} / \mathrm{ha})$ & 30.6 & 26.3 & 3.25 & 2.79 \\
\hline $\mathrm{T}_{3}: \mathrm{N}, \mathrm{P}_{2} \mathrm{O}_{5}, \mathrm{~K}_{2} \mathrm{O}(20,60,30 \mathrm{~kg} / \mathrm{ha})$ & 34.3 & 28.5 & 3.39 & 2.81 \\
\hline $\mathrm{T}_{4}: \mathrm{N}, \mathrm{P}_{2} \mathrm{O}_{5}, \mathrm{~K}_{2} \mathrm{O}(30,90,45 \mathrm{~kg} / \mathrm{ha})$ & 37.8 & 29.3 & 3.36 & 2.69 \\
\hline $\mathrm{T}_{5}: \mathrm{N}, \mathrm{P}_{2} \mathrm{O}_{5}, \mathrm{~K}_{2} \mathrm{O}(10,30,15 \mathrm{~kg} / \mathrm{ha})+0.1$ tons $/$ ha V.C & 36.1 & 28.2 & 2.86 & 2.24 \\
\hline $\mathrm{T}_{6}: \mathrm{N}, \mathrm{P}_{2} \mathrm{O}_{5}, \mathrm{~K}_{2} \mathrm{O}(20,60,30 \mathrm{~kg} / \mathrm{ha})+0.1$ tons/ha V.C & 39.8 & 30.3 & 2.99 & 2.27 \\
\hline $\mathrm{T}_{7}: \mathrm{N}, \mathrm{P}_{2} \mathrm{O}_{5}, \mathrm{~K}_{2} \mathrm{O}(30,90,45 \mathrm{~kg} / \mathrm{ha})+0.1$ tons/ha V.C & 42.3 & 31.0 & 3.00 & 2.20 \\
\hline $\mathrm{S}, \mathrm{Em} \pm$ & 1.62 & 0.97 & - & - \\
\hline C.D & 5.05 & 3.03 & - & - \\
\hline
\end{tabular}

Note: Green fodder - Rs.2.5/kg; Vermicompost: Rs 12/kg; N Rs. 11.95/kg; $\mathrm{P}_{2} \mathrm{O}_{5}$ Rs. 50/kg; $\mathrm{K}_{2} \mathrm{O}$ Rs. 28.3/kg. 
registered during both years (2019 and2020) in all treatments (Table 3 ). Data presented in Table 2 revealed that the treatment $\mathrm{T}_{7}$ recorded higher green fodder yield than $\mathrm{T}_{5}, \mathrm{~T}_{3}, \mathrm{~T}_{2}$ and $\mathrm{T}_{1}$ during both years (2019 and 2020). However $\mathrm{T}_{7}$ registered marginally higher green fodder yield than $T_{6}$ and $T_{4}$. The higher growth characters (plant height and dry matter accumulation) in treatment $T_{7}$ were the reason for higher green fodder yield than rest of the treatments. Verma et al., (2017) also recorded higher biological yield of soybean in integrated fertility management. Furthermore, higher straw yield of soybean was reported by Jagdeesh et al., (2018) in treatments receiving integrated nutrient sources.

The treatment $\mathrm{T}_{3}\left(\mathrm{~N}, \mathrm{P}_{2} \mathrm{O}_{5}, \mathrm{~K}_{2} \mathrm{O}(20,60,30 \mathrm{~kg} / \mathrm{ha})\right.$ recorded higher benefit cost ratio of 3.39 in 2019 and 2.81 in 2020 compared to other treatments. The reason for higher $B: C$ in treatment $T_{3}$ is due to lower cost of cultivation compared to $\mathrm{T}_{7}, \mathrm{~T}_{6}, \mathrm{~T}_{5}, \mathrm{~T}_{4}$ and higher green fodder yield compared to $T_{2}$ and $T_{1}$.

\section{CONCLUSION}

The present investigation revealed that application of $\mathrm{N}$, $\mathrm{P}_{2} \mathrm{O}_{5}, \mathrm{~K}_{2} \mathrm{O}(30,90,45 \mathrm{~kg} / \mathrm{ha})$ along with 0.1 tons $/ \mathrm{ha}$ vermicompost recoded higher green fodder productivity of soybean. However, the higher benefit cost ration was observed with application of $\mathrm{N}, \mathrm{P}_{2} \mathrm{O}_{5}, \mathrm{~K}_{2} \mathrm{O}(20,60,30 \mathrm{~kg} / \mathrm{ha}$. Thus it may be concluded that for higher fodder production of soybean $\mathrm{N}, \mathrm{P}_{2} \mathrm{O}_{5}, \mathrm{~K}_{2} \mathrm{O}(30,90,45 \mathrm{~kg} / \mathrm{ha})$ along with 1.0 tons/ha vermicompost should be applied. But, for higher economic returns only chemical fertilizers $\mathrm{N}, \mathrm{P}_{2} \mathrm{O}_{5}, \mathrm{~K}_{2} \mathrm{O}(20$, $60,30 \mathrm{~kg} / \mathrm{ha}$ should be applied.

\section{REFERENCES}

Chaudhari, L.S., Mane, S.S. and Giri S.N. (2019). Growth, yield and quality of soybean as influenced by INM. International Journal Pure and Applied Bioscience. 7(2): 209-212.

IGFRI Vision, (2050). Indian Grassland and Fodder Research Institute, Jhansi (UP).

Jagdeesh, M., Tripathi, R.K., Kumawat, N., Singh, M., Yadav, R.K., Tomar, I.S. and Sahu, Y.K. (2018). Influence of organic and inorganic fertilizers on grwth, yields and nutrient uptake of soybean (Glyscine max Merril L.) under Jhabua Hills. International Journal of Current Microbiology and Applied Sciences. 7(02): 725-30.

Maheshbabu, H.M., Hunje, R., Patil, B.N.K. and Babalad, H.B. (2008). Effect of organic manures on plant growth, seed yield and quality of soybean. Karnataka Journal of Agricultural Sciences. 21(2): 219-221.

Raja, W. (2013). Suitable cropping system and weed management practices for high fodder oat production. Indian Journal of Weed Science. 45(3): 201-203.

Rehman, U. and Raja, W. (2020). Performance forage sorghum with different forage legumes under temperate condition of Kashmir. Forage Research. 46(3): 248-253.

Verma, S.N., Sharma, M. and Verma, A. (2017). Effect of integrated nutrient management on growth, quality and yield of soybean [Glycine max]. Annals of Plant and Soil Research. 19(4): 372-376. 